\title{
DESERTION AND NON-SUPPORT IN FAMILY CASE WORK
}

\author{
By Joanna C. Colcord,
}

Superintendent, New York Charity Organization Society.

\section{Legalistic Conception of Desertion}

An examination of the existing literature on family desertion brings to light surprisingly little regarding the problems it presents to the social case worker. There have been several statistical studies of its occurrence, and innumerable discussions of its treatment from the legal side, but the case worker in search of technical advice and direction browses over a wide field with comparatively small result. This is probably due to the fact that the rise of the domestic relations courts in late years has tended to turn the thoughts of those interested in the problem toward the legal and judicial remedies which are being developed. It may further be due to the fact that workers in the field of adult probation, who constitute the specialized group of case workers most directly interested in family desertion, are still breaking new ground and have not as yet been able to make the contribution to the literature of the case work movement that we may confidently expect to have from them in the course of the next few years.

Whatever the cause or causes, it seems true that desertion is generally written about as a breach of the law, to be dealt with through the correctional agencies of the community. This is not so much an erroneous as a distorted view of the problem. It fails to take into account the loss and wastage in human life, and emphasizes rather the financial burden of dependency which is laid upon society. Both elements of course exist, and must be recognized no less by lawyers and judges than by social workers in any effective program for the treatment and prevention of desertion.

It may as well be admitted that the hopes which social workers entertained at the beginning of the domestic relations courts movement have not been in all respects realized. What the social worker hoped for was an institution which would administer justice based upon the principles of social case work; but while much has been gained, we still fall far short of this. The law still insists upon 
regarding the important element in family desertion to be the deserter's evasion of his financial responsibility and the rendering of his family a public charge. That there can be degrees of culpability in the deserter, aside from the financial question, is not always apparent to the legal mind. The chairman of a case committee, a lawyer, and one of the most large-hearted and compassionate of men, maintained that the graver fault of a young deserter who had left his wife and two infants penniless in a strange city, while he went on a three-weeks pleasure trip, lay in the fact that he had embezzled fifty dollars from his employer to finance the excursion!

There is still much confusion as to the location and extradition of deserters, and in most cities the burden of finding the missing husband and serving the summons upon him is still unrelentingly placed upon the shoulders of the wife. Extradition from without the state is made difficult by lack of appropriations, and by the indifference of district attorneys who feel that no good end is served by bringing a man back on a felony charge to serve a prison sentence, on the ground that "he will be of no more use to his family here than there." A study made by Mr. William $\mathrm{H}$. Baldwin of prison terms served by returned deserters indicates that these are not usually long enough to act as a real deterrent. Indeed, so involved is the question of extradition, that one sympathizes with the bewilderment of the social worker in New York, who said: "As far as I can see, if a man deserts and goes across the ferry to Jersey City he is guilty of a felony, but if he gets as far as Buffalo he is only a disorderly person!" Another anomaly is that contained in the proposition that the wife can claim abandonment only on behalf of her children. A man living with his wife and five-year-old boy in an eastern city, eloped with another woman to a city in the middle west. The couple kidnapped the boy and took him with them, and the distracted mother, bereft of both husband and child, had no recourse in any court, since the father was continuing to provide for his son.

These are instances, however, of shortcomings in the law rather than in the technique of dealing with desertion by correctional means. Under the latter heading, unsatisfactory results are most often to be ascribed to the reliance which some of the courts still place upon the contrasted statements of the husband and wife, supported it may be by the testimony of their respective friends. To the legal mind it may seem an heretical statement, but the social 
worker is convinced that testimony concerning family desertion which is drawn out in court, and unsupported by any careful social investigation by a trained worker, is often worse than useless. The causes of this particular form of family breakdown are often too obscure to be apparent to the persons immediately concerned, even if both are honestly trying to give a straight account, and if one or both are not making such effort, the advantage goes to the side that can put up the better story. When a sufficient number of welltrained probation officers are attached to the court to make the necessary preliminary investigations, this danger does not exist; otherwise it is always present. There is something about the factors involved in desertion cases, that seems naturally to arouse the prejudices of the individual who deals with them. Women social workers are notoriously prone to take the part of the woman without giving the man a hearing in cases of marital difficulty; employers are equally likely to feel that there is much to be said on the man's side, especially if they have never seen the wife. The only way in which this perfectly human tendency can be corrected, is either to make or have made for one a careful, skilful and painstaking inquiry into the real facts of the case, obtained from as many well-informed and disinterested sources as possible. In other words, until the courts which deal with social problems like desertion and non-support will consent to abandon their traditional dislike for "hearsay evidence" presented and gathered by social workers, they will fall short of administering the highest quality of social justice.

\section{Social Conception of Desertion}

The effect of centering the treatment of deserters and their families in the courts has brought about, even in the mind of the social worker, the feeling that they constitute a class by themselves, presenting problems different from those of other families, and calling for an entirely different technique in their handling. Dr. E. W. Eubank, who has recently made a careful survey of the problem in Chicago and other cities of the United States, makes as one of his leading recommendations the suggestion that social agencies dealing with families, attempt, so far as possible, to center the handling of desertion cases in one person or department. There is room for a good deal of difference of opinion on this point, and its advisability may well be questioned for more than one reason. While a certain 
facility is gained through having the dealings with the courts, district attorneys, etc., in the hands of one or a few people, the plan necessarily prevents other members of the staff engaged in general case work from the opportunity of handling the whole problem in desertion cases. Furthermore, it only confirms and extends the tendency to regard deserters and their families as a class apart. The experienced case worker knows that desertion is in itself only a symptom of some more deeply seated trouble in the family structure. It constitutes a "presenting symptom" which does, indeed, indicate some one of a few specified forms of treatment at the outset, but which also involves all of the foresight, patience and skill which the social case worker knows how to apply, if any sort of permanent reconstruction is to be accomplished. Behind a man's abandonment of his home and family there is sure to be a wide variety of causes, some external and easily to be recognized; others rooted deeply in the subconscious instincts and aversions of the people concerned. What these individuals are able to tell is often strangely petty and inadequate without the interpretation which applied psychology is able to give. One man stated that what gave him the final impulse to leave home was his wife's filling his bed with ashes. As legal evidence, this would seem ridiculous; to the social worker who had studied the two temperaments closely, it was an interesting and significant detail.

In this way a great number of widely different family problems seem to be superficially alike only because the breakdown has become so acute that the actual physical disruption in family life has begun. The case worker recognizes that while the absence of the man involves certain difficulties in the finding of him and in the possibility of getting information from him, the case problem which he and his family present is not essentially different from what it would have been before his departure if the problem could have been recognized and brought to her attention earlier. She recognizes that the causes of desertion are as numerous and varied as the causes of poverty, if these could be ascertained, and that they are likely to be even more subtle and difficult of appraisement. Many influences from without are impinging on the home and the family at the present time to bring about a slackening in the bonds which hold it together. Considering the unrest and unnatural stresses and strains of urban life, the wonder probably is that desertion has not increased more rapidly than it has. 
Keeping in mind all this, the case worker sees desertion as only an acute form of the symptoms of weakened and crumbling family life. She is unwilling to accept the common theory which divides the treatment of desertion into two fields: one, the location, apprehension and punishment of the man through the courts, and the other, the charitable relief of his family during the process. Instead, she holds that the technique of the case treatment of the deserter and his family is no different in essentials from social case treatment in general except perhaps in the one particular of locating the absconder. She does not believe that reconciliations can be brought about by short-cut methods. Most social workers have a deepseated distrust, not of the principle that a function of the domestic relations courts is to bring about such reconciliations, but rather of the way in which such efforts have been made in connection with many of them. The wholesale attempt to patch the tattered fabric of family life in a series of hurried interviews held in the court room, and without any information about the problem except what can be gained from the two people concerned, can hardly be of permanent value in most cases. It is natural that case workers, keenly aware as they are of the long, slow, and difficult process involved in character-rebuilding, look askance at court-made reconciliations. With the best will in the world the people who attempt this delicate service very often have neither the time nor the facts about the particular case in question to give the skilful personal service necessary to reconstruction. As a result many weak-willed wrong-doers are encouraged to take a pledge of good conduct which they will not, or cannot, keep; and other individuals who feel themselves deeply wronged go away with an additional sense of those wrongs having been underestimated and of having received no redress. The results are written in discouragement and in repeated failures to live in harmony, each of which makes a permanent solution more and more difficult. The case worker to whom the results of the externally imposed reconciliation come back again and again has reason to be confirmed in her distrust of short-cut methods. In order to demonstrate which contention is right there is great need for a careful study, made one or two years after the reconciliation has taken place, of a large group of couples, the solution of whose troubles has been attempted in this way. Unless there should be supervision for a considerable period by a 
skilful and resourceful probation officer all experience points to the conclusion that the percentage of permanent reconciliations would be low.

\section{Social Case Treatment of Desertion}

While it is true that the deserter and his family present no unique problem to the case worker, it is nevertheless true that certain adaptations in case work technique are usually advisable and that certain points must be especially kept in mind in the course of the investigation. ${ }^{1}$ Disparity of age, of race or nationality and of religion are significant factors when they are found in connection with this form of family breakdown. Not less important is a conception of differences which may exist between the couple in the matter of education, habits, social status and moral and ethical concepts. A history of the background of the man and the woman from childhood on, keeping all these factors in mind, is essential to an understanding of the problem. One extremely important fact to have in mind, and one which should be proved or disproved where possible in connection with every desertion case by means of records of vital statistics, is whether or not the marriage was a forced one. There can be little doubt from the experience of case workers that people who contract this type of marriage later find their way in large numbers to the courts of domestic relations. A piece of research quite as desirable as the investigation of quick reconciliations recommended above, would be a study of the married life from the point of view of the community of several hundred families in which a forced marriage had been brought about through the urging of relatives, the church, the court, or those social workers, now diminishing in numbers, who still believe that to legitimatize the child and to "give the girl a name" are desiderata sufficiently important to justify forcing together against their inclination the prospective parents of more children.

In the treatment of desertion and similar problems the sex factor is, of course, an extremely important one. The tendency of most social workers is either to ignore this as largely as possible or to theorize about it to such an extent that it serves, as with the Freudians, for an explanation for every phase of human behavior.

${ }^{1}$ See questionnaire on The Deserted Family, "Social Diagnosis," by M, E. Richmond, p. 395. 
It is on the whole safer to embrace the first alternative than the second, but the best work in the handling of desertion cases will be done by the person who neither shuts his eyes to this phase of the matter nor unduly emphasizes it. The majority of social case workers are unmarried women under forty, and in this particular respect they frequently find themselves handicapped by the natural reluctance of the deserter to discuss his conception of the marital relation in such a way as to be enlightening to them, as well as by the chivalrous attitude which the married woman of the tenements often adopts toward her unmarried visitor. The decisive statement "You have never been married so you cannot understand" often proves at least a temporary barrier in dealing with deserted wives just as the similar statement "You have never been a mother so you cannot know the feelings of one" is used to block her efforts in another direction. If it is found impossible to carry on the necessary discussions rationally and without too serious embarrassment, it is often possible to call upon the socially-minded physician or clergyman for help along this line.

This, of course, presupposes that the man in the case has been located and can be interviewed; but the fact that in the majority of cases of desertion this cannot be attained without great difficulty is in itself the most serious handicap which the case worker meets in the treatment of desertion. In the location of absconding husbands undoubtedly the greatest single contribution has been that made by the National Desertion Bureau, a private organization which specializes in the location of deserters of the Jewish faith. Its use of widespread newspaper publicity, including the publishing of photographs of missing men, has been widely imitated by other social agencies. In locating absconding husbands it is more than usually important to learn accurately facts concerning their trade connections, membership in social organizations, employment records, etc. Foreign language newspapers are usually willing to print personal inquiries, or even photographs, and trade journals have been successfully employed in the location of even non-union men connected with the trades. The Post Office Department, if convinced that the public welfare demands it, might be induced to entrust reputable social agencies with forwarding addresses. If the husband has deserted for financial reasons, or has left home as the result of a quarrel, his location is a much easier matter than if there 
is reason to believe he has absconded with another woman. Although the clues are in this instance doubled since two persons are involved, the pains taken to elude detection are usually greater.

Under ideal police conditions all this ground work of tracing deserters could be done by detectives, who already secure from the post office and all the other sources mentioned, information that furnishes clues. After the man is located through coöperation between the detective bureau and the case worker in charge the man can be interviewed by her or her correspondent.

In the attempt of social workers to locate missing husbands they are somewhat at a disadvantage. The general tendency to believe that the man is invariably in the wrong, and the policy of arresting him first and perhaps letting him explain afterwards, make even a man who has a good deal of excuse to offer for his course, reluctant to permit himself to be communicated with. Case workers are now beginning seriously to question whether in the long run the best policy is not after all to interview the man, or to have him interviewed and to give him an opportunity to state his side of the case before causing a warrant for his arrest to be taken out. The attempt to do this will sometimes result in a second disappearance, but if the man's return can be accomplished voluntarily there is many times the basis upon which to build. The deserter, or at least the first-time deserter, must not be prejudged without a hearing. In spite of the discouraging average of desertion cases, this particular man may not be in the average class, and in that case it would spell injustice both to him and to his family to treat him as though he were.

Some years ago a charity organization society, which maintained a special bureau for the treatment of desertion cases, was asked by a Mrs. Clara Williams to help her find her husband, John, who had left her some years previously and was living with another woman, so that she might force him to contribute to the support of herself and her two children. Mrs. Williams² was a motherly appearing person who kept a clean, neat home, and seemed to take excellent care of her children. She was voluble concerning her husband's misdeeds and very bitter toward him, which seemed only natural. The fact of the other household was corroborated from other sources, and Mr. Williams' work references indicated that he had been quar-

${ }^{2}$ These names are fictitious. 
relsome and difficult for his employers to get along with, although a competent workman. The problem seemed to the desertion agent a perfectly clear and uncomplicated one and he proceeded to handle it according to the formula. Some very clever detective work followed, in the course of which the man was traced from one suburban city to another, and his present place of employment found in the city where his wife lived, although he lived in another state. The warrant was served upon the man as he stepped from the train on his way to work, and he appeared in domestic relations court. He did not deny the desertion but made some attempt to bring counter charges against his wife. When questioned about his present mode of living he became silent and refused to testify further. He was placed under bond, which was furnished by the relatives of the woman with whom he was living, to pay his wife $\$ 6.00$ a week. No probation was thought necessary and the case was closed, both the court and the charity organization society crediting themselves with a case successfully handled and terminated.

About a year later Mrs. Williams again applied, stating that her husband's bond had lapsed, that his payments had ceased, and that she had no knowledge of his whereabouts. Although her home and children were still immaculate she failed to satisfy the social worker who this time visited her home with the plausible statements which she had made before. The children's health was not good and they seemed unnaturally repressed and unhappy. Ugly reports concerning Mrs. Williams' drinking habits came to the society. The school teacher deplored the effect which the morbid nature of Mrs. Williams was having on her youngest child, a daughter just entering adolescence. The son, a boy a little older, was listless and unsatisfactory at his work, and defiant and secretive toward any attempt to get to know him better. He spent many nights away from home and was evidently not on good terms with his mother. As soon as Mrs. Williams saw that real information was desired she began indulging in fits of rage in which she displayed such an exaggerated ego as to cause some doubts as to her mentality. Baffled at every turn the case worker decided to see the man, if possible, and have a long talk with him to see if through him any clue to the situation might be gained. The first step was to gain the confidence of a former fellow-workman and friend of his who now maintained his own small shop. This was done after several visits, and upon the 
social worker's solemn promise "not to have a policeman hidden behind a tree" the deserting husband consented to an evening meeting in his friend's shop. A most illuminating interview followed. Mr. Williams was found to be an intelligent though melancholy and self-centered man. The couple had married somewhat late in life, it being Mrs. Williams' second marriage. She had been strongly influenced by her mother to marry him and had never had any real affection for him. It became very evident from his story that the strongly developed egotism of both the husband and wife had made a real marriage impossible between them, and the visitor became convinced of the genuineness of Mr. Williams' protestations that he endured the constant abuse and ill-treatment of his wife as long as it had been possible to do so. As her drinking habits took more hold upon her and he had realized that the break was coming he had endeavored to place the children in homes, and had once had his wife taken into court where her plausible story and good appearance resulted in the case being dismissed with a reprimand to the husband. He then left home but continued to send her money at intervals, although as he got older he was able to earn less at his trade. Socialism was his religion, and it was his preaching of this doctrine in season and out to his fellow workmen which had earned him the ill-will of his employers. He defended his present mode of living vigorously, putting up a strong argument that it was a real marriage, whereas the other had only been a sham. He spoke in terms of affection of the woman who was giving him the only real home he had ever known, and only wished that the state of public opinion would permit his taking his young daughter into his home. The boy, he realized, had grown entirely away from him and they could never mean anything to each other. It was his habit to make frequent trips back to the region where his family lived in order that he might stand on the corner and watch his children go by. He gave readily much information about his own and his wife's past connections, including the addresses of many of her relatives whose existence she had denied, and he successfully proved that her claims as to his lapsed payments were false by producing the entire series of post office receipts covering his remittances to her and extending down to the very week of the interview.

It is true that this is not a "typical desertion case" such as Miss Brandt describes in her study of deserted women, but is it not 
equally true that the handling of this one case problem according to legalistic and juridical formulae meant a real miscarriage of justice and the possible sending to shipwreck of two young lives to follow the old? It is experiences such as these which have confirmed in the case worker a determination to avoid formulae and to treat each case problem, in so far as possible, as something entirely new.

\section{Desertion in Relation to the Community}

It must not be denied that there is basis for the contention that just as a community can regulate its own death rate within limits, so it can by repressive measures regulate its desertion rate. The sort of prevention, however, that keeps the would-be deserter in the home which constantly grows less of a home, simply through fear of the consequences if he left it, hardly seems so desirable from the social point of view as that form of prevention which would provide for such homes and families the wise, skilled and sympathetic treatment which is the ideal of social case work. There are no figures to show that either method has been sufficiently brought into play in any one community to bring about any marked change in the number of desertions. Dr. Eubank in preparation for his pamphlet, circularized charity organization societies in a number of cities and got widely different opinions as to whether desertion was on the decrease, was stationary, or was on the increase. These were merely opinions and not the result of statistical studies. In New York City, Dr. Devine made a study of five thousand cases known to the Charity Organization Society in the years 1906 to 1908 and of this number exactly 10 per cent were deserted wives. Ten years later, in 1916, a somewhat similar study was made of three thousand families known to the same society in the course of that year. The percentage of deserted wives was found to be almost the same, namely 9.9 per cent. The statistics of the New York Charity Organization Society for the last year show 492 deserted wives out of 4,204 , or about 11.7 per cent. This nearly stationary percentage over the eleven-year period is probably only a coincidence as these particular ten years have seen marked population changes as well as the establishment in the city of a Domestic Relations Court, the Bureau of Domestic Relations and the National Desertion Bureau. It may, however, be taken to indicate that the type of desertion which leads to dependency is not markedly on the increase. 
Echoes which have reached us already from Europe point to great and sweeping changes in the conceptions of family life which are likely to result from the great war. Inevitably our own standards must be affected since we are learning that not only in a political sense is it true that the lives of all the nations are one. Home Service workers are recognizing that no small part of their task is to help keep strong and firm the bonds which bind the soldier on another continent to his family on this. Perhaps never before has there been the need for careful study and alert watchfulness on the part of the social workers in this country, so that the changes which come are not unanticipated. No one group in the community, surely, is in better position to bear testimony as to the strength and weakness of family life, the changing conceptions regarding it, and the strains and stresses from which it may still be protected. 